\title{
In-hospital mortality of patients with cardiogenic shock after acute myocardial infarction; impact of early revascularization
}

\author{
Kashif Ali Hashmi ${ }^{1}$, Khawar Abbas ${ }^{1}$, Atif Ali Hashmi², Muhammad Irfan², Muhammad Muzzammil Edhi ${ }^{3}$, \\ Nauman Ali $^{1}$ and Amir Khan ${ }^{4^{*}}$ (1)
}

\begin{abstract}
Objectives: The purpose of this study was to determine the frequency of in-hospital mortality in 351 patients who developed cardiogenic shock after acute myocardial infarction and by determining this; we might find that how efficiently we could manage this serious condition in our population by knowing the factors which are associated with high mortality after cardiogenic shock. Moreover impact of early revascularization like thrombolytic therapy or angioplasty was also evaluated.

Results: Mean age was $65.41 \pm 7.78$ years in our study. In-hospital mortality with cardiogenic shock after acute myocardial infarction was found to be $44.73 \%$. Significant association of in-hospital mortality was noted with age, hypertension, diabetes mellitus and BMI. Patients receiving early revascularization were noted to have lower in-hospital mortality compared to those in whom revascularization was not done due to delayed presentation. This study concluded that there is a high frequency (44.73\%) of in-hospital mortality in patients with cardiogenic shock after acute myocardial in our population. So, we recommend that for achieving a good outcome and to reduce in-hospital mortality; in addition to rapid diagnosis of this condition, underlying risk factors like hypertension and diabetes should be evaluated and managed accordingly and early revascularization should be done when possible.
\end{abstract}

Keywords: Ischemic heart disease, Cardiogenic shock, In hospital mortality, Acute myocardial infarction

\section{Introduction}

Cardiogenic shock is defined as inadequate tissue perfusion due to primary failure of the heart to function effectively [1-3]. Cardiogenic shock is the leading cause of death after acute myocardial infarction (MI). In the absence of aggressive highly experienced technical care, mortality rates among patients with cardiogenic shock are exceedingly high (up to 70-90\%). The key for achieving a good outcome is rapid diagnosis, prompt supportive therapy, and expeditious coronary artery revascularization in patients with myocardial ischemia and infarction [4-6]. Evidence of right ventricular

\footnotetext{
*Correspondence: dramirkhan04@gmail.com

${ }^{4}$ Kandahar University, Kandahar, Afghanistan

Full list of author information is available at the end of the article
}

dilation on echocardiogram may indicate a worse outcome in patients with cardiogenic shock [7].

A study conducted by Bagai et al., showed that frequency of in-hospital mortality rates in older patients with cardiogenic shock after acute myocardial infarction was $39.1 \%$ versus $4.5 \%$ in patients without shock [8]. Another study done by Kunadian et al., showed that frequency of overall in-hospital mortality of patients with cardiogenic shock after acute myocardial infarction was $35.5 \%$ with no sex difference (male: $35.8 \%$ vs female: $35 \%$ ) [9]. A study conducted at Punjab institute of cardiology Lahore (PIC) showed that frequency of emergency cardiac deaths due to cardiogenic shock was noted to be $74 \%$ [10]. Another study showed that frequency of 30 day mortality of patients with cardiogenic shock after acute myocardial infarction was (50.6\%) [11]. 
In the current study, we aimed to evaluate the frequency of in-hospital of patients who develop cardiogenic shock after myocardial infarction and to determine factors which are associated with high mortality. With better understanding of the associated co-morbidities, we might be able to device protocols in loco-regional population to reduce in-hospital mortality in these patients. Moreover impact of early revascularization like thrombolytic therapy or angioplasty was also evaluated.

\section{Main text}

\section{Inclusion criteria}

Patients of cardiogenic shock developing after acute myocardial infarction of age 50-80 years, admitted in Chaudhry Pervaiz Elahi Institute of Cardiology, Multan were included in this study.

\section{Methods}

The duration of the study was from January 2014 till December 2017. After approval from ethical review committee, total number of 351 patients with cardiogenic shock (systolic blood pressure $<90 \mathrm{mmHg}$ for at least $30 \mathrm{~min}$ or need for vasopressor to maintain systolic blood pressure $>90 \mathrm{mmHg}$ ) after acute myocardial Infarction admitted to the Ch. Pervaiz Elahi institute of Cardiology, Multan, fulfilling the Inclusion/Exclusion criteria were selected. After taking informed written consent, the demographic information like name, age, sex, address and risk factors like diabetes mellitus (DM), hypertension (HTN) and smoking were recorded for each patient. After provision of informed written consent, status of diabetes, hypertension and smoking was assessed. Patients who received early revascularization (thrombolytic therapy or angioplasty) were recorded. BMI was calculated by following formula; BMI = weight in kilograms/ height in meters [2]. All the patients were followed during their hospital stay. Frequency of deaths was observed in patients of cardiogenic shock after acute myocardial infarction during their hospital stay.

\section{Data analysis}

Data was analyzed by using statistical package for social sciences (SPSS) version 21. Mean and standard deviation were computed for quantitative variable and frequency and percentage were calculated for qualitative variables. Stratification was done with regards to qualitative variables to see the effect of these modifiers on study groups by using Chi square test. Odds ratio was calculated by medcalc online calculator. Normality was checked through histogram as well as Shapiro-wilk test. $p$ value of $\leq 0.05$ was considered as significant.

\section{Results}

Out of 351 patients, 246 (70.1\%) were male and 105 (29.9\%) were female. The mean age of patients was $65.4 \pm 7.7$. Mean weight and height was $95.3 \pm 13.1 \mathrm{~kg}$ and $169.8 \pm 11.8 \mathrm{~cm}$ respectively. Mean BMI was $26.41 \pm 7.49 \mathrm{~kg} / \mathrm{m} 2$. Among 351 patients, 143 (40.7\%) patients were found with diabetes mellitus, 231 (65.8\%) with hypertension while 137 (39\%) patients were obese. Mean duration of diabetes, hypertension and smoking was $16.3 \pm 11.7$ years, $14.52 \pm 9.68$ years and $13.87 \pm 5.59$ years respectively as presented in Table 1 . Revascularization was done for $70(20.5 \%)$ patients. In our study, in hospital mortality was found to be $44.7 \%$ (157 patients). Stratification was done and post stratification Chi square test was applied. The results showed significant association of in hospital mortality with age $(\mathrm{p} \leq 0.0001)$, diabetes mellitus $(\mathrm{p} \leq 0.0001)$, hypertension $(p=0.029)$ and BMI $(p \leq 0.0001)$ while insignificant association was found with gender $(p=0.821)$. Detailed results of association are presented in Table 2. Significant association of in-hospital mortality was also found with patients receiving revascularization $(\mathrm{p}=0.014)$. Patients without revascularization were found to have high mortality $(\mathrm{OR}=0.50)$ as presented in Table 3.

\section{Table 1 Descriptive statistics of study population}

\begin{tabular}{ll}
\hline & $\mathbf{n}(\%)$ \\
\hline Age $\left(\right.$ years) $^{\mathrm{a}}$ & $65.41 \pm 7.78$ \\
Hypertension duration (years) Diabetes mellitus duration (years) & $14.52 \pm 9.68$ \\
Smoking duration (years) & $16.34 \pm 11.65$ \\
Weight $(\mathrm{kg})$ & $13.87 \pm 5.59$ \\
Height $(\mathrm{cm})$ & $95.26 \pm 13.09$ \\
BMl (kg/m $\left.{ }^{2}\right)$ & $169.81 \pm 11.78$ \\
Sex & $26.41 \pm 7.49$ \\
Male & \\
Female & $246(70.1)$ \\
Diabetes mellitus & $105(29.9)$ \\
Yes & \\
No & $143(40.7)$ \\
Hypertension & $208(59.3)$ \\
Yes & \\
No & $231(65.8)$ \\
BMl & $120(34.2)$ \\
Obese $\left(\geq 30 \mathrm{~kg} / \mathrm{m}^{2}\right)$ & \\
Non obese $\left(<30 \mathrm{~kg} / \mathrm{m}^{2}\right)$ & $137(39)$ \\
Revascularization & $214(61)$ \\
Yes & \\
No & $72(20.51)$ \\
\hline
\end{tabular}

${ }^{a}$ Mean \pm SD 
Table 2 Association of in-hospital mortality with risk factors

\begin{tabular}{|c|c|c|c|c|}
\hline & \multicolumn{2}{|c|}{ In-hospital mortality n (\%) } & \multirow[t]{2}{*}{$p$ value } & \multirow[t]{2}{*}{ Odds ratio $(95 \% \mathrm{Cl})$} \\
\hline & Yes $(n=157)$ & No $(n=194)$ & & \\
\hline \multicolumn{5}{|l|}{ Sex } \\
\hline Male & $111(70.7)$ & $135(69.6)$ & 0.821 & $1.05(0.66-1.67)$ \\
\hline Female & $46(29.3)$ & $59(30.4)$ & & \\
\hline \multicolumn{5}{|l|}{ Age group (years) } \\
\hline$\leq 60$ & $35(22.3)$ & $82(42.3)$ & 0.000 & NA \\
\hline $61-70$ & $73(46.5)$ & $66(34)$ & & \\
\hline$>70$ & $49(31.2)$ & $46(23.7)$ & & \\
\hline \multicolumn{5}{|l|}{ Diabetes mellitus } \\
\hline Yes & $91(58)$ & $62(32)$ & 0.000 & $2.93(1.89-4.54)$ \\
\hline No & $66(42)$ & $132(68)$ & & \\
\hline \multicolumn{5}{|l|}{ Hypertension } \\
\hline Yes & $113(72)$ & $118(60.8)$ & 0.029 & $1.65(1.05-2.59)$ \\
\hline No & $44(28)$ & 76 (39.2) & & \\
\hline \multicolumn{5}{|l|}{ BMI } \\
\hline Obese $\left(\geq 30 \mathrm{~kg} / \mathrm{m}^{2}\right)$ & $84(53.5)$ & $53(27.3)$ & 0.000 & $3.06(1.96-4.77)$ \\
\hline Non obese $(<30$ kg/m²) & $73(46.5)$ & $141(72.7)$ & & \\
\hline
\end{tabular}

Chi square test was applied

$p$-value $\leq 0.05$, considered as significant

Table 3 Association of in-hospital mortality with early revascularization

\begin{tabular}{lrrrr}
\hline Revascularization & \multicolumn{2}{l}{$\begin{array}{l}\text { In-hospital mortality } \\
\mathbf{n}(\mathbf{\%})\end{array}$} & p-value & $\begin{array}{l}\text { Odds ratio } \\
(\mathbf{9 5 \%} \mathbf{C l})\end{array}$ \\
\cline { 2 - 4 } & $\begin{array}{l}\text { Yes } \\
(\mathbf{n}=\mathbf{1 5 7})\end{array}$ & $\begin{array}{l}\text { No } \\
(\mathbf{n}=\mathbf{1 9 4})\end{array}$ & & \\
\hline Yes & $23(14.6)$ & $49(25.3)$ & 0.014 & $0.50(0.29-$ \\
No & $134(85.4)$ & $145(74.7)$ & & $0.87)$
\end{tabular}

Chi square test was applied

$p$-value $\leq 0.05$, considered as significant

\section{Discussion}

In the present study, we found a high frequency of inhospital mortality (44.7\%) in patients that develop cardiogenic shock after myocardial infarction in loco-regional population. We also found that mortality risk was associated with age, diabetes, BMI and hypertension. Moreover, there is a significant impact of early revascularization in reducing mortality in patients developing cardiogenic shock after myocardial infarction.

Cardiogenic shock is the most common cause of death in patients that are hospitalized with acute myocardial infarction [12-14]. Many retrospective analyses have concluded that survival in patients with cardiogenic shock that undergo coronary angioplasty is higher than in patients that do not undergo angioplasty
[15-20]. Cardiogenic shock owing to acute myocardial infarction (AMI) portends a poor prognosis [14]. It accounts for the vast majority of deaths in all types of AMI $[21,22]$. Literature review revealed that in-hospital mortality after myocardial infarction range from 12 to $85 \%$ in different centers [23-29]. The differences are largely due to presence of underlying co-morbidities, risk factors and provision of early aggressive interventions like angioplasty. Moreover, development of cardiogenic shock is the major factor leading to increase in mortality after myocardial infarction.

Zhang et al. [23] found mortality with cardiogenic shock after myocardial infarction in Chinese population to be $83 \%$ which is higher compared to all previously described studies. We didn't find any difference in in-hospital mortality between male and female patients. A study done by Wong et al. [24] concluded that despite differences in patient characteristics including age, history of diabetes and prior CABG between women and men, there was no significant sex difference in in-hospital mortality associated with MI complicated by cardiogenic shock. An extensive review by Vaccarino et al. [30] based on 27 published reports from 1966 through 1994 reported no difference in early mortality between women and men with cardiogenic shock after myocardial infarction.

Age is major factor governing the risk of mortality after myocardial infarction with a higher risk of mortality in patients older than 75 years [24]; on the other 
hand, early revascularization decreases this risk. A large non-randomized SHOCK Registry demonstrated a markedly lower adjusted risk of in-hospital mortality for those aged 75 years or older that were clinically selected to undergo early revascularization [31]. Singh et al. [11] in their study found increasing age, diabetes mellitus, hypertension and smoking as a strong predictors for in-hospital mortality in patients with cardiogenic shock after myocardial infarction and found a positive relationship between them and mortality rates.

Overall, it was concluded that in-hospital mortality in patients with cardiogenic shock after myocardial infarction is very high; moreover increasing age and co-morbid conditions (hypertension, diabetes mellitus) are very strong predictors of in-hospital mortality after acute myocardial infarction and demands immediate management measures. In the absence of aggressive, highly experienced technical care, mortality rates among patients with cardiogenic shock are exceedingly high (up to $70-90 \%$ ).

\section{Conclusion}

This study concluded that there is a high frequency $(44.73 \%)$ of in-hospital mortality in patients with cardiogenic shock after acute myocardial in our population and is associated with increasing age, hypertension, diabetes mellitus and obesity. So, we recommend that for achieving a good outcome and to reduce in-hospital mortality; in addition to rapid diagnosis of this condition, underlying risk factors like hypertension and diabetes should be evaluated and managed accordingly and early revascularization should be done when possible.

\section{Limitations}

The major limitation of the study was that, it represents a single institution data. Moreover, data regarding time delay from onset of symptoms till the patients reached hospital and access to regional health care services was not available. Similarly, history of previous episodes of myocardial infarctions and surgeries including CABG was taken into account and long term follow-up was not done.

\section{Abbreviations}

MI: myocardial infarction; DM: diabetes mellitus; HTN: hypertension.

\section{Authors' contributions}

$\mathrm{KAH}$ and $\mathrm{KA}$ : main author of manuscript, have made substantial contributions to conception and design of study. AAH, MI, MME, NA and AK have been involved in requisition, analysis of the data and gave final approval and revision of the manuscript. All authors read and approved the final manuscript.

\section{Author details}

${ }^{1}$ Chaudhry Pervaiz Elahi Institute of Cardiology, Multan, Punjab, Pakistan. ${ }^{2}$ Liaquat National Hospital and Medical College, Karachi, Sindh, Pakistan. ${ }^{3}$ Brown

University, Providence, RI, USA. ${ }^{4}$ Kandahar University, Kandahar, Afghanistan.

\section{Acknowledgements}

We gratefully acknowledge all staff members of Cardiology Department, Chaudhry Pervaiz Elahi Institute of Cardiology Multan, Punjab, Pakistan for their help and cooperation.

\section{Competing interests}

The authors declare that they have no competing interests.

\section{Availability of data and materials}

The datasets used and analyzed during the current study are available from the corresponding author on request.

\section{Consent to publish}

Not applicable.

Ethics approval and consent to participate

Ethics committee of Chaudhry Pervaiz Elahi Institute of Cardiology Multan, Punjab, Pakistan approved the study. Written informed consent was obtained from the patients for the participation.

Funding

Not applicable.

\section{Publisher's Note}

Springer Nature remains neutral with regard to jurisdictional claims in published maps and institutional affiliations.

Received: 4 June 2018 Accepted: 9 October 2018

Published online: 11 October 2018

\section{References}

1. Van de Werf F, Bax J, Betriu A, Blomstrom-Lundqvist C, Crea F, Falk V, et al. Management of acute myocardial infarction in patients presenting with persistent ST-segment elevation: the Task Force on the Management of ST Segment Elevation Acute Myocardial Infarction of the European Society of Cardiology. Eur Heart J. 2008;29(23):2909-45.

2. Rippe JM, Irwin RS. Irwin and Rippe's intensive care medicine. Philadelphia: Lippincott Williams \& Wilkins; 2003.

3. Marino PL. The ICU book. Baltimore: Williams \& Wilkins; 1998.

4. Babaev A, Frederick PD, Pasta DJ, Every N, Sichrovsky T, Hochman JS Trends in management and outcomes of patients with acute myocardial infarction complicated by cardiogenic shock. JAMA. 2005;294(4):448-54.

5. Fox KA, Steg PG, Eagle KA, Goodman SG, Anderson FA Jr, Granger CB, et al. Decline in rates of death and heart failure in acute coronary syndromes, 1999-2006. JAMA. 2007;297(17):1892-900.

6. Jeger RV, Radovanovic D, Hunziker PR, Pfisterer ME, Stauffer JC, Erne $P$, et al. Ten-year trends in the incidence and treatment of cardiogenic shock. Ann Intern Med. 2008;149(9):618-26.

7. Hamon M, Agostini D, Le Page O, Riddell JW, Hamon M. Prognostic impact of right ventricular involvement in patients with acute myocardial infarction: meta-analysis. Crit Care Med. 2008;36(7):2023-33.

8. Bagai A, Chen AY, Wang TY, Alexander KP, Thomas L, Ohman EM, et al. Long-term outcomes among older patients with non-ST segment elevation myocardial infarction complicated by cardiogenic shock. Am Heart J. 2013;166(2):298-305.

9. Kunadian V, Qiu W, Bawamia B, Veerasamy M, Jamieson S, Zaman A, et al. Gender comparisons in cardiogenic shock during st elevation myocardial infarction treated by primary percutaneous coronary intervention. Am J Cardiol. 2013;112(5):636-41.

10. Hochman JS, Sleeper LA, Webb JG, Dzavik V, Buller CE, Aylward P, et al. For the SHOCK investigators. Early revascularisation and long-term survival in cardiogenic shock complicating acute myocardial infarction. JAMA. 2006:295:2511-5 
11. Singh M, White J, Hasdai D, Hodgson PK, Berger PB, Topol EJ, et al. Long-term outcome and its predictors among patients with ST-segment elevation myocardial infarction complicated by shock: insights from the GUSTO-I trial. J Am Coll Cardiol. 2007;50(18):1752-8.

12. Hochman JS, Buller CE, Sleeper LA. Cardiogenic shock complicating acute myocardial infarction: etiologies, management and outcome: overall findings of the SHOCK Trial Registry. J Am Coll Cardiol. 2000;36:1063-70.

13. Webb JG, Sanborn TA, Sleeper L. Percutaneous coronary intervention for cardiogenic shock in the SHOCK Trial Registry. Am Heart J. 2001;141:964-70.

14. Holmes DR Jr, Bates ER, Kleiman NS, Sadowski Z, Horgan JH, Morris DC, Califf RM, Berger PB, Topol EJ. Contemporary reperfusion therapy for cardiogenic shock: the GUSTO-I trial experience. J Am Coll Cardiol. 1995;26:668-74

15. Lee L, Bates ER, Pitt B, Walton JA, Laufer N, O'Neill WW. Percutaneous transluminal coronary angioplasty improves survival in acute myocardial infarction complicated by cardiogenic shock. Circulation. 1988;78:1345-51.

16. Lee L, Erbel R, Brown TM, Laufer N, Meyer J, O'Neill WW. Multicenter registry of angioplasty therapy of cardiogenic shock: initial and long term survival. J Am Coll Cardiol. 1991;17:599-603.

17. Disler L, Haitas B, Benjamin J, Steingo L, McKibbon J. Cardiogenic shock in evolving myocardial infarction: treatment by angioplasty and streptokinase. Heart Lung. 1987;16:649-52.

18. Verna E, Repetto S, Boscarini M, Ghezzi I, Binaghi G. Emergency coronary angioplasty in patients with severe left ventricular dysfunction or cardiogenic shock after acute myocardial infarction. Eur Heart J. 1989;10:58-66.

19. Meyer P, Blanc P, Baudouy M, Morand P. Treatment de choc cardiogenique primaire par angioplastie transluminale coronarienne a la phase aigue de l'infarctus. Arch Mal Coeur. 1990;83:329-34.

20. Hibbard M, Holmes DR Jr, Bailey KR, Reeder GS, Bresnahan JF, Gersh BS. Percutaneous transluminal coronary angioplasty in patients with cardiogenic shock. J Am Coll Cardiol. 1992;19:636-49.

21. Holmes DR Jr, Hasdai D. Cardiogenic shock cimplicating non-STsegment elevation acute coronary syndrome. In: Hasdai D, Berger PB, Batter A, editors. Cardiogenic shock: diagnosis and treatment. New Jersey: Humana Press; 2002. p. 35-42.
22. Berger PB, Hasdai D. Cardiogenic shock complicating ST-segment elevation acute coronary syndrome. In: Hasdai D, Berger PB, Batter A, editors. Cardiogenic shock: diagnosis and treatment. New Jersey: Humana Press; 2002. p. 43-56.

23. Shah ST, Shah SFA, Shah I, Khan SB, Hadi A, Gul AM, et al. Frequency of adverse outcomes of acute myocardial infarction in patients with stress hyperglycemia. Pak Heart J. 2012;45(01):43-7.

24. Wong SW, Sleepe LA, Monrad ES, Menegus MA, Palazzo A, Dzavik V, et al. Absence of gender differences in clinical outcomes in patients with cardiogenic shock complicating acute myocardial infarction. J Am Coll Cardiol. 2001;38(5):1395-401.

25. Berger PB, Tuttle RH, Holmes DR Jr, Topol EJ, Aylward PE, Horgan JH, et al. One-year survival among patients with acute myocardial infarction complicated by cardiogenic shock, and its relation to early revascularization. Circulation. 1999;99:873-8.

26. Hands ME, Rutherford JD, Muller JE, Davies G, Stone PH, Parker C, et al. The in-hospital development of cardiogenic shock after myocardial infarction: incidence, predictors of occurrence, outcome and prognostic factors. J Am Coll Cardiol. 1989;14(1):40-6.

27. Killip T, Kimball JT. Treatment of myocardial infarction in a coronary care unit. A two-year experience with 250 patients. Am J Cardiol. 1967;20:457-64.

28. Tipoo FA, Quraishi AR, Najaf SM, et al. Outcome of cardiogenic shock complicating acute myocardial infarction. J Coll Physicians Surg Pak. 2004;14:6-9.

29. Carnendran L, Abboud R, Sleeper LA. Trends in cardiogenic shock: report from the SHOCK study Should we emergently revascularize. Occluded Coronaries for cardiogenic shock? Eur Heart J. 2001;22:472-8.

30. Vaccarino V, Krumholz HM, Berkman LF, Horwitz RI. Sex differences in mortality after myocardial infarction. Is there evidence for an increased risk for women? Circulation. 1995;91:1861-71.

31. Dzavik V, Sleeper LA, Cocke TP. Early revascularization is associated with improved survival in elderly patients with acute myocardial infarction complicated by cardiogenic shock: a report from the SHOCK Trial Registry. Eur Heart J. 2003;24:828-37.
Ready to submit your research? Choose BMC and benefit from:

- fast, convenient online submission

- thorough peer review by experienced researchers in your field

- rapid publication on acceptance

- support for research data, including large and complex data types

- gold Open Access which fosters wider collaboration and increased citations

- maximum visibility for your research: over $100 \mathrm{M}$ website views per year

At $\mathrm{BMC}$, research is always in progress.

Learn more biomedcentral.com/submissions 